\title{
Kitchen Waste Disposal and Management Practices in Urban Region of Bangladesh through Barrel Composting System
}

\author{
Mohammad Rasel Mahmud ${ }^{1}$, Md. Sirajul Islam²*, Nowara Tamanna Meghla ${ }^{3}$, \\ Md. Humayun Kabir ${ }^{4}$, Muhammad Jasim Uddin ${ }^{5}$ \\ 1,2,3,4,5 Department of Environmental Science and Resource Management, Mawlana Bhashani Science and \\ Technology University, Tangail-1902, Bangladesh \\ *Corresponding Author (Email: islammstazu@yahoo.com)
}

How to cite this paper: Mahmud, M.R., Islam, M.S., Meghla, N.T., Kabir, M.H. and Uddin, M.J. (2019). Kitchen Waste Disposal and Management Practices in Urban Region of Bangladesh through Barrel Composting System. Grassroots Journal of Natural Resources, 2(4): 1-12. Doi: https://doi.org/10.33002/nr2581.6853.02041

Received: 12 October 2019

Reviewed: 31 October 2019

Provisionally Accepted: 04 November 2019

Revised: 15 November 2019

Finally Accepted: 30 November 2019

Published: 31 December 2019

Copyright (C) 2019 by author(s) and

The Grassroots Institute.

This work is licensed under the Creative Commons Attribution International License (CC BY 4.0).

http://creativecommons.org/licenses/by/4.0/
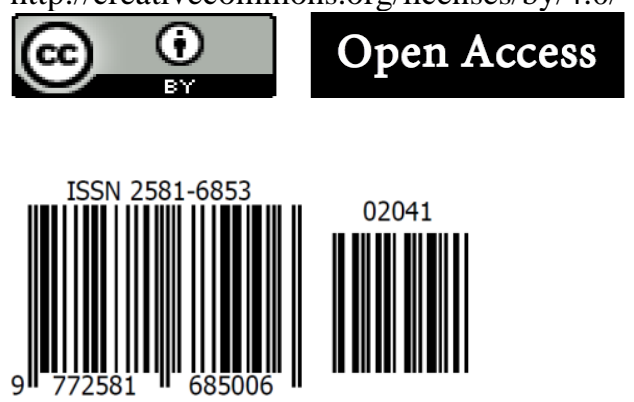

\begin{abstract}
The present paper is based on a study that was performed to assess the kitchen waste management through barrel composting system in order to produce organic fertilizer, and to investigate the physicochemical properties $(\mathrm{pH}$ and moisture content) including nutrient contents (OC, N, P, K and $\mathrm{S}$ ) and heavy metal concentration $(\mathrm{Pb}, \mathrm{Cd}$ and $\mathrm{Cr}$ ) of the produced organic fertilizer during the period from July 2016 to June 2017 in the urban area of Tangail region. Kitchen wastes were collected twice in a week for 6 months from 2 halls of Mawlana Bhashani Science and Technology University (MBSTU) and 2 wards of Tangail municipality and divided into 2 phases. About $5.8 \mathrm{~kg}$ organic fertilizer was produced from $178.52 \mathrm{~kg}$ kitchen waste, which was highly enriched with nutrients. The $\mathrm{pH}$ of the composts was increased and moisture contents $\left(67\right.$ to $71 \%$ in $1^{\text {st }}$ phase and 36 to $44 \%$ in $2^{\text {nd }}$ phase) were decreased with duration and waste dried up period. Finally, moisture content ranged from 23 to $31 \%$. The produced organic fertilizer contained organic carbon (24.42 to $27.68 \%$ ), total nitrogen (2.035 to $2.533 \%), \mathrm{C} / \mathrm{N}$ ratio (10.07 to 12 ), phosphorus (0.735 to $0.872 \%$ ), potassium (2.83 to $3.89 \%$ ) and sulphur (0.578 to $0.68 \%)$. The $\mathrm{Pb}$ concentration exceeded in green barrel, whereas it was negligible in black barrel. The $\mathrm{Cd}$ and $\mathrm{Cr}$ concentrations in both types of barrels were within permissible level.
\end{abstract}

\section{Keywords}

Kitchen waste; Barrel compositing; Organic fertilizer; Heavy metals 
Doi: https://doi.org/10.33002/nr2581.6853.02041

\section{Introduction}

Kitchen waste is one kind of solid waste which is produced from the kitchen during the time of preparing and processing of food that makes a large portion (50-60\%) of the total solid waste generated in Bangladesh (Rahman and Ali, 2000). These organic substances are bulky to handle and contribute to numerous liquid and gaseous emissions that deteriorate dumpsite environments. The waste generation rate was $0.41 \mathrm{~kg} / \mathrm{capita} /$ day in urban area of Bangladesh, while waste collection efficiency varied from 37 to $77 \%$ with an average of 55\% (Rahman and Ali, 2000). Huge amount of uncollected wastes, a high proportion of which are organic, creates nuisance and pollutes the local environment rapidly that needs appropriate treatment (Bahauddin and Uddin, 2012). Composting is a method of organic solid waste treatment and barrel composting is one of the affordable, easiest and cheapest process by which compost is produced that can reduce the weight and volume of waste, and can produce an inoffensive and useful product (Islam et al., 2011). The process of composting can take as little as 3-6 months. Ideally, compost is matured for 3-4 months before use. This finished product is high in carbon and nitrogen and is used in landscaping, horticulture and agriculture as a soil conditioner and fertilizer (Sambali and Mehrotra, 2009). Besides, it is the eco-friendly process that can enhance the biodiversity and environment (Rahman and Ali, 2000). Finally composting can be a profitable business and provide income and employment opportunities for the poor (Rahman and Ali, 2000). The uses of compost fertilizers are gaining popularity day by day amongst farmers in Bangladesh (BBS, 2012) and recently its demand is gradually increasing, and its circle is extended to peri urban and urban areas (Dilkara et al., 2016). The vermicompost application showed higher result for growth and yield indices and nutrient content when compared with conventional aerobic compost used for vegetables production (Islam et al., 2016). Vermicompost is enriched with beneficial microbes to increase the organic fertilizer value and reduce the dose of application. The vermicompost increases nitrogen and phosphorous availability by enhancing biological nitrogen fixation and phosphorous solubilization (Padmavathiamma, Li and Kumari, 2008). In conventional aerobic composting, biological aerobic transformation takes place whereas different organic product can be added to the soil without detrimental effects of crop growth (Baca, Fornasier and Nobil, 1992). Composts provide all nutrients in readily available forms and also enhance uptake of nutrients by plants. The compost plays a major role in improving growth and yield of different field crops production (Sreenivas, Muralidhar and Rao, 2000).

The Mawlana Bhashani Science and Technology University (MBSTU), Bangladesh has five halls occupied by 1000 students and staff, and the Tangail municipality has a total population of 128,785 where the municipality consists of 21,115 households with a density of population $3650 / \mathrm{km}^{2}$ (Tangail Municipality, 2006). Every day a large amount of wastes produced from the kitchen of these halls and municipal areas. The waste is thrown here and there, producing bad odor, spreading flies, rodents vector diseases. Islam et al. (2011) conducted a study on MBSTU campus and found that the kitchen waste management through barrel composting system can provide a solution dealing with the most significant component of waste. It reduced the weight and volume of waste and produced inoffensive and useful product which was also enough for existing university gardening. This compost can be used by farmers in place of expensive and energy-intensive artificial fertilizers. So it is necessary to establish a model of waste management system in MBSTU campus and the Tangail municipality area by converting kitchen waste into organic fertilizer and compost in a continuous process to build awareness among the urban people regarding the sustainable use and management of kitchen waste within the university and the community. The 
main objective of this study is to identify the best management practice of kitchen waste through barrel composting system to reduce the volume of kitchen wastes and to convert it into the organic fertilizer through composting which is used for vegetable and flower gardening in the study area.

\section{Materials and Methods}

The study was conducted in two student halls of Mawlana Bhashani Science and Technology University namely Bangabandhu Sheikh Mujibur Rahman Hall (St-1) and Shaheed Janani Jahanara Imam Hall (St-2); (Figure 1) and two wards of Tangail municipality namely Akurtakur Para (St-3) and Thana Para (St-4) (Figure 1). The reference period of the study is one year from July 2016 to June 2017.

Sample collection: A green barrel (GB), which is considered as standard and a black barrel (BB), which is to determine the changes with respect to green barrel, were placed at each station. The barrels placed were named as GB-1 and BB-1 in St-1, GB-2 and BB-2 in St-2, GB-3 and BB-3 in St-3, and GB-4 and BB-4 in St-4. The residues of different vegetables and spices such as onion, garlic, ginger and piper were collected from kitchen twice a week in the afternoon on regular basis for a period of 6 months. The wastes were weighed with balance and then dumped into the barrels for composting.

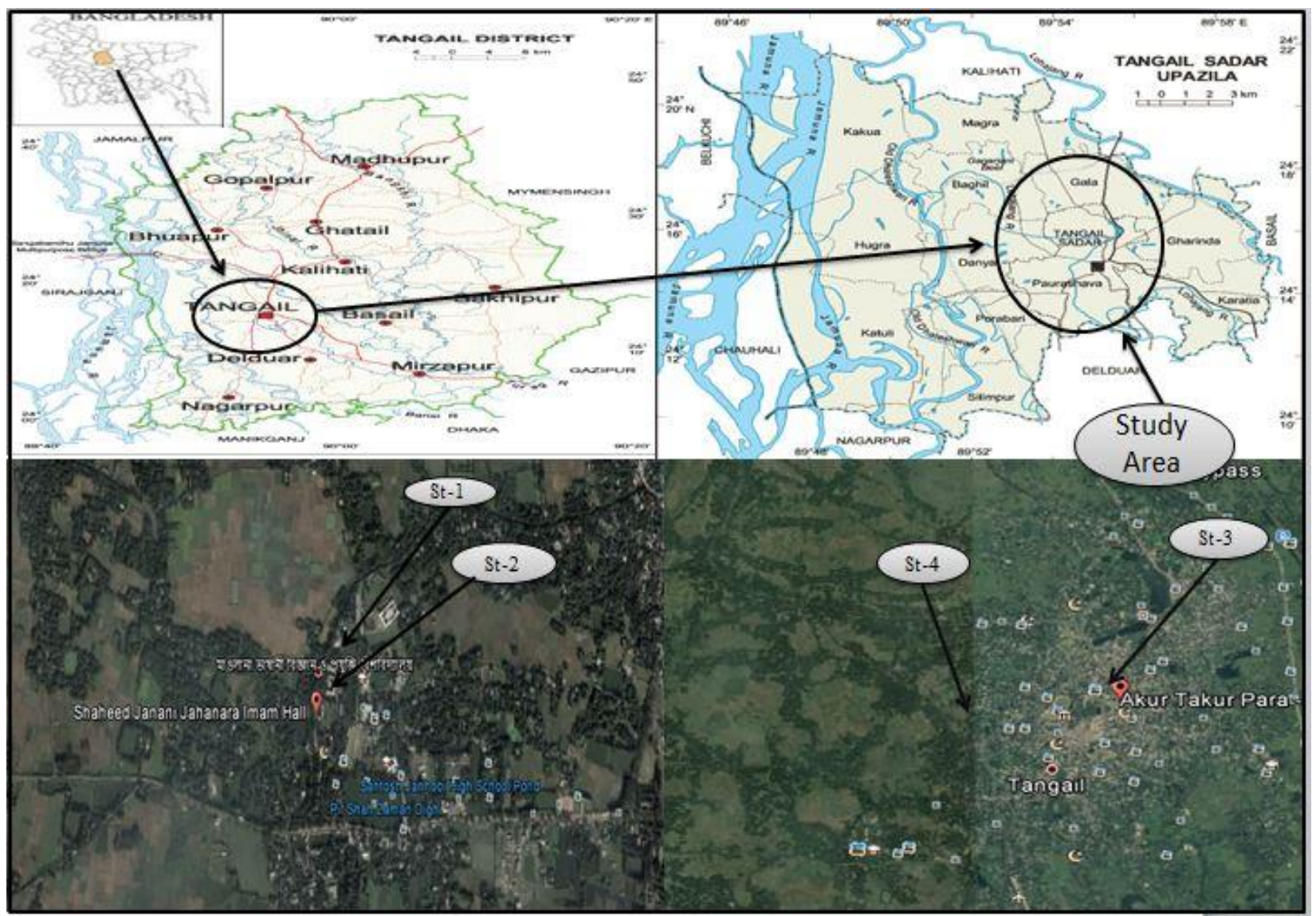

Figure 1: Maps and images showing the study area in MBSTU campus and Tangail municipality area (Banglapedia, 2016; Google Earth, 2017) 
Conversion procedure: The conversion of compost from kitchen waste was carried out by Barrel Composting System that takes limited space and is easy to handle. The process was continued for a period of 6 months where first 3 months were considered as $1^{\text {st }}$ phase and later 3 months considered as $2^{\text {nd }}$ phase. The temperature was measured for 4 times a day (morning, noon, afternoon and night) when the barrels were fully packed with wastes. After 7 days of dumping (when the volume of waste was significantly reduced), wastes were dumped into black barrel for 4 days to compare the change of characteristics of compost. A $100 \mathrm{ml}$ water was added into black barrel and was stirred for 3-5 minutes. Three months later, at least 3 samples were collected from each type of barrels and brought to the laboratory to measure the temperature, $\mathrm{pH}$ and moisture content. In the same way, after 6 months, at least 3 samples were taken from the barrels to measure its temperature, $\mathrm{pH}$ and moisture content assuring that the compost is made. Then the samples were oven dried for 24 hours and weight was taken by electric balance. At next step, the samples were examined in the laboratory to measure the quality of organic fertilizer.

Sample analysis: Temperature and $\mathrm{pH}$ of the waste were measured by using thermometer and digital $\mathrm{pH}$ meter. The moisture content was estimated by the following equation: Moisture content $(\%)=[\{($ wet weight-dry weight $) /$ wet weight $\} \mathrm{x} 100]$. The organic carbon was estimated by Walkley and Black's wet oxidation method, total nitrogen by Kjeldhal's method, phosphorus by vanado-molydo-phosphoric acid method, potassium by flame photometry method and Di-acid $\left(\mathrm{HNO}_{3}-\mathrm{HCLO}_{4}\right)$ digestion was used for the estimation of sulphur in compost samples (Goyal, Dhull and Kapoor, 2005; Sundberg and Smars, 2004). The presence of $\mathrm{Pb}, \mathrm{Cd}$ and $\mathrm{Cr}$ in produced organic fertilizer was measured by Atomic Absorption Spectrophotometer (Model: AA-7000).

\section{Results and Discussion}

\section{Produced organic fertilizers}

A total of $5.80 \mathrm{~kg}$ organic fertilizer was produced from $178.52 \mathrm{~kg}$ kitchen wastes, where $3.064 \mathrm{~kg}$ was produced in green barrel and $2.736 \mathrm{~kg}$ in black barrel. This waste is highly enriched with nutrients. In both types of barrels, the highest amount of organic fertilizer was produced at St-1. On the other hand, lowest amount of waste was produced at St-2 (Figure 2). At St-3 and St-4, more or less same amount of kitchen wastes was disposed, and almost same amount of organic fertilizer was produced. The produced organic fertilizers were enough for existing university gardening, organic farming and other purposes.

\section{Physicochemical parameters of organic fertilizer}

\section{Temperature}

The broad range of optimum temperatures for composting process is from $45^{\circ} \mathrm{C}$ to $65^{\circ} \mathrm{C}$ (Sundberg and Smars, 2004). The range of temperature for optimal composting is between $52^{\circ} \mathrm{C}$ and $60^{\circ} \mathrm{C}$, whereas lower temperatures might be more suitable for composting (Zein, Seif and Gooda, 2015). During the period of dumping, the atmospheric temperature was within the range from $26.4^{\circ} \mathrm{C}$ to $28.6^{\circ} \mathrm{C}$ that indicated shiny weather. In the $1^{\text {st }}$ phase of the composting process, the temperature was ranged from $24.7^{\circ} \mathrm{C}$ to $37.2^{\circ} \mathrm{C}$ in green barrel (GB); it was $24.3^{\circ} \mathrm{C}$ to $39.1^{\circ} \mathrm{C}$ in black barrel (BB). The temperature of both the types of barrels was similar and showed mesophilic $\left(<40^{\circ} \mathrm{C}\right)$ nature (Table 1). The highest temperature was measured in BB-3 $\left(37.25^{\circ} \mathrm{C}\right)$ and lowest in $\mathrm{GB}-4$ 
$\left(35.02^{\circ} \mathrm{C}\right)$. The temperature was raised sharply at noon from the morning with highest at afternoon and decreased at night. The rise in temperature in the composting barrel was mainly due to the exothermic reactions associated with the respiratory metabolism of the microorganisms involved in the composting process. It confirmed the study of Sundberg and Smars (2004) and Tchobanglous (1977). In the $2^{\text {nd }}$ phase of the composting processes, the highest temperature was measured in BB$3\left(31.3^{\circ} \mathrm{C}\right)$ and lowest in $\mathrm{GB}-1\left(30.5^{\circ} \mathrm{C}\right)$ with a range from 29.1 to $32.1^{\circ} \mathrm{C}$ indicating rapid decomposition and production of the organic fertilizer. In both the phases, the temperature of black barrel was higher than the green barrel, which could be due to the addition of extra water in the black barrel. In home container composting system, the temperature never reached above $30^{\circ} \mathrm{C}$ (Sambali and Mehrotra, 2009) which was observed in the entire study period.

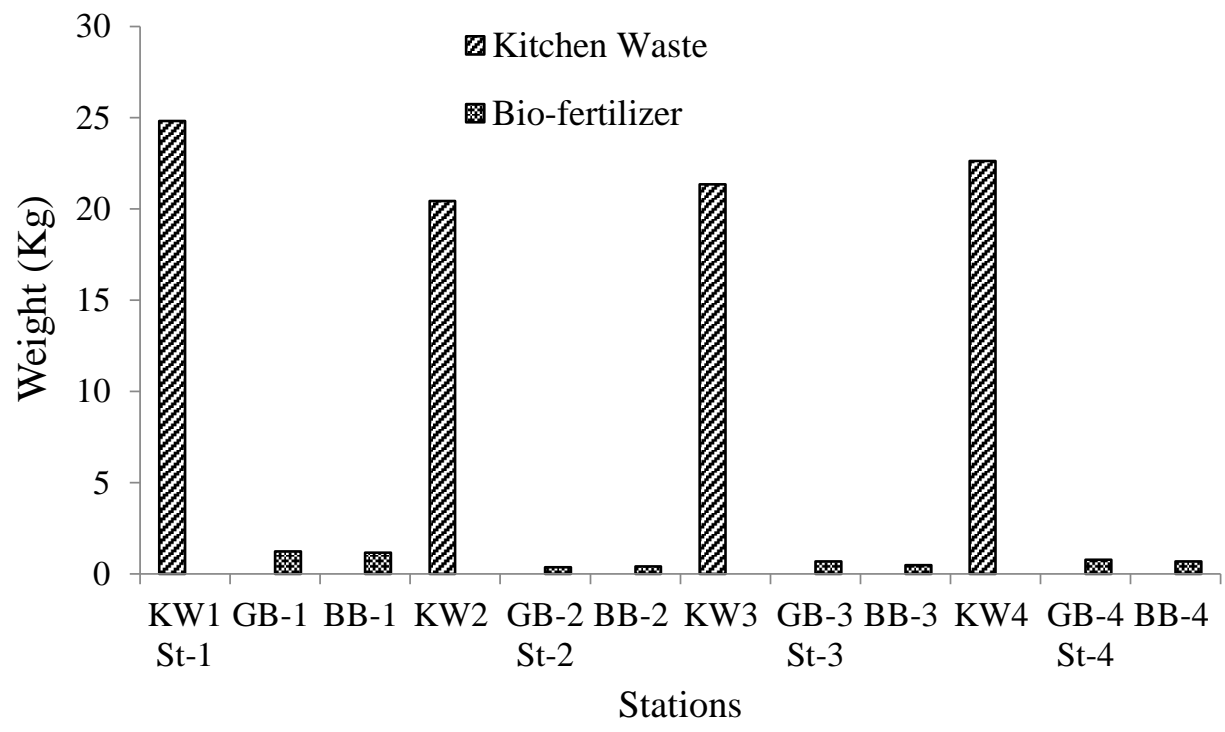

Figure 2: Amount of kitchen wastes used to produce organic fertilizers

Table 1: The temperature, $\mathrm{pH}$ and moisture content of kitchen waste composting process

\begin{tabular}{cccccccc}
\hline \multicolumn{2}{c}{ Sampling } & \multicolumn{2}{c}{ Temperature $\left({ }^{\circ} \mathrm{C}\right)$} & \multicolumn{2}{c}{$\mathrm{pH}$} & \multicolumn{2}{c}{ Moisture (\%) } \\
\hline Stations & Barrels & $1^{\text {st }}$ phase & $2^{\text {nd }}$ phase & $1^{\text {st }}$ phase & $2^{\text {nd }}$ phase & $1^{\text {st }}$ phase & $2^{\text {nd }}$ phase \\
\hline St-1 & GB-1 & $35.59 \pm 2.81$ & $30.5 \pm 1.45$ & $6.89 \pm 1.18$ & $9.34 \pm 0.10$ & $67 \pm 0.12$ & $37 \pm 0.12$ \\
& BB-1 & $37.07 \pm 2.44$ & $31.1 \pm 1.62$ & $7.05 \pm 1.02$ & $8.81 \pm 0.19$ & $70 \pm 0.10$ & $44 \pm 0.11$ \\
St-2 & GB-2 & $35.58 \pm 2.38$ & $30.9 \pm 1.56$ & $6.76 \pm 0.68$ & $8.21 \pm 0.10$ & $69 \pm 0.10$ & $40 \pm 0.13$ \\
& BB-2 & $36.86 \pm 1.87$ & $31.1 \pm 1.76$ & $7.04 \pm 0.89$ & $8.27 \pm 0.26$ & $71 \pm 0.12$ & $39 \pm 0.16$ \\
St-3 & GB-3 & $35.26 \pm 1.96$ & $30.8 \pm 1.81$ & $6.92 \pm 0.81$ & $8.36 \pm 0.12$ & $67 \pm 0.10$ & $36 \pm 0.13$ \\
& BB-3 & $37.25 \pm 2.30$ & $31.3 \pm 1.70$ & $7.05 \pm 0.77$ & $8.13 \pm 0.25$ & $69 \pm 0.10$ & $42 \pm 0.12$ \\
St-4 & GB-4 & $35.02 \pm 1.93$ & $30.9 \pm 1.55$ & $6.92 \pm 0.84$ & $8.54 \pm 0.12$ & $67 \pm 0.10$ & $41 \pm 0.11$ \\
& BB-4 & $37.17 \pm 2.49$ & $31.2 \pm 2.03$ & $7.16 \pm 1.06$ & $8.39 \pm 0.55$ & $70 \pm 0.10$ & $43 \pm 0.11$ \\
\hline
\end{tabular}

$p H$

The $\mathrm{pH}$ of organic material ranged from 5.5 to 8.5 which is a good indicator for decomposition (Li and Zhang, 2000). The highest and lowest $\mathrm{pH}$ in GB was 9.37 and 6.13, respectively, both at S-1; while in $\mathrm{BB}$, the highest and lowest $\mathrm{pH}$ was 9.3 (at S-4) and 6.13 (at S-1), respectively (Table 1). In first month, $\mathrm{pH}$ was lower than next two months indicating that organic acids were formed 
having bad odour. After completion of $1^{\text {st }}$ phase composting process, the $\mathrm{pH}$ was increased because of more decomposition of organic matter (Fang and Wong, 1999). The microorganisms of compost operate best under the $\mathrm{pH}$ ranged from 5.5 to 8.0 (CWMI, 1996). The $\mathrm{pH}$ of green and black barrel waste was within the range of 5.5 to 8 that indicated microbial operation for decomposition was carried out. The $\mathrm{pH}$ of green barrel waste ranged from 8.03 to 9.47 in $2^{\text {nd }}$ phase composting process. The highest and lowest $\mathrm{pH}$ in GB was 9.47 (at S-1) and 8.03 (at S-2), respectively. In BB, the highest and lowest $\mathrm{pH}$ was 9.3 (at S-4) and 7.73 (at S-4), respectively. When the composting proceeds, the organic acids get neutralized. Mature compost generally has a pH between 6 and 8 (CWMI, 1996). The $\mathrm{pH}$ of matured compost ranged from 7.73 to 9.18 in both barrels. The result showed that the $\mathrm{pH}$ in both barrels was almost similar and alkaline in nature indicating that the compost was matured, and organic fertilizer is produced.

\section{Moisture content (\%)}

The moisture content is the water which is essential for metabolic processes (Sharma, 2003). At $>65 \%$ moisture content, anaerobic condition develops causing bad odours as well as the depletion of the aerobic bacteria (Goyal, Dhull and Kapoor, 2005). At <40\% moisture content, bacterial activity for decomposition is reduced (Rahman, 2004). In $1^{\text {st }}$ phase of composting process, the moisture content in both types of barrels was higher than $65 \%$ in most cases. Thus, decomposition rate was slow with some bad odour. The average moisture content in GB and BB was $68.5 \%$ and $71 \%$, respectively (Table 1 ). After completion of $1^{\text {st }}$ phase of composting process, the kitchen waste was gradually dried up by solar radiation and then moisture content was decreased gradually. The reduction in moisture content was observed at all stations in $2^{\text {nd }}$ phase of composting process with an average of $38.5 \%$ in GB and $42 \%$ in BB. The average moisture in both green and black barrels was below 50\% which was lower than the study of Islam et al. (2011). Comparing with GB, the moisture content in BB was almost nearest to the standard while a little higher amount due to adding of water and stirring. The mature compost was almost dry in physical appearance.

\section{Nutrient content of organic fertilizer}

\section{Organic carbon $(O C)$}

The content of organic carbon in composted fertilizer was ranged from 24.73 to $26.05 \%$ in GB, whereas the highest and lowest organic carbon content was $26.05 \%$ at St-2 and $24.73 \%$ at St-3, respectively (Table 2). In BB, the highest and lowest organic carbon content was $27.68 \%$ at St-2 and $24.42 \%$ at St-1, respectively (Table 2). The result of the study showed that the contents of organic carbon in both GB and BB at all the stations were more or less within the standard (10 to 25\%) set by NACC (2015). So, it can be said that the organic fertilizer is rich in organic carbon. It is suitable for different purposes like organic farming, agriculture, gardening, and harvesting of crops.

\section{Total nitrogen (TN)}

The content of total nitrogen in organic fertilizer ranged from 2.103 to $2.533 \%$ in GB and 2.035 to $2.441 \%$ in BB which was within the standard level (0.5 to $4.0 \%)$ of NACC (2015). The ratio of the carbon to nitrogen (\% of dry weight) is a key indicator of the suitability of composts as a growth medium. For good compost, ideal C/N ratio is 12 to 18 (Cal Recycle, 2006). The C:N ratio in GB was 12, 12, 10.92 and 10.07; and in BB 12, 12, 11.84 and 11.24 at St-1, St-2, St-3 and St-4, respectively indicating good quality of organic fertilizer (Table 2). 
Doi: https://doi.org/10.33002/nr2581.6853.02041

Table 2: Nutrient content of organic fertilizers produced from both green and black barrels

\begin{tabular}{|c|c|c|c|c|c|c|}
\hline \multirow[t]{2}{*}{ Parameters } & \multirow{2}{*}{$\begin{array}{c}\text { Sampling } \\
\text { stations }\end{array}$} & \multicolumn{2}{|c|}{ Green barrel } & \multicolumn{2}{|c|}{ Black barrel } & \multirow{2}{*}{$\begin{array}{c}\text { Standard } \\
(\mathrm{NACC}, 2015)\end{array}$} \\
\hline & & Average & Range & Average & Range & \\
\hline Organic & St-1 & 25.23 & & 24.42 & & \multirow{5}{*}{$10-25$} \\
\hline \multirow[t]{4}{*}{ Carbon (\%) } & St-2 & 26.05 & 24.73 & 27.68 & 24.42 & \\
\hline & St-3 & 24.73 & to & 25.37 & to & \\
\hline & St-4 & 25.51 & 26.05 & 27.43 & 27.68 & \\
\hline & Mean & 25.38 & & 26.23 & & \\
\hline Total & St-1 & 2.103 & & 2.035 & & \multirow{5}{*}{$0.5-4$} \\
\hline \multirow[t]{4}{*}{ Nitrogen $(\%)$} & St-2 & 2.171 & 2.103 & 2.307 & 2.035 & \\
\hline & St-3 & 2.263 & to & 2.142 & to & \\
\hline & St-4 & 2.533 & 2.533 & 2.441 & 2.441 & \\
\hline & Mean & 2.27 & & 2.23 & & \\
\hline \multirow{5}{*}{$\begin{array}{l}\text { Phosphorous } \\
(\%)\end{array}$} & St-1 & 0.842 & & 0.79 & & \multirow{5}{*}{$0.5-1.5$} \\
\hline & St-2 & 0.869 & 0.842 & 0.763 & 0.735 & \\
\hline & St-3 & 0.874 & to & 0.758 & to & \\
\hline & St-4 & 0.847 & 0.874 & 0.735 & 0.79 & \\
\hline & Mean & 0.86 & & 0.76 & & \\
\hline \multirow{5}{*}{$\begin{array}{l}\text { Potassium } \\
(\%)\end{array}$} & St-1 & 3.89 & & 3.326 & & \multirow{5}{*}{$1-3$} \\
\hline & St-2 & 3.722 & 3.287 & 2.834 & 2.834 & \\
\hline & St-3 & 3.526 & to & 3.156 & to & \\
\hline & St-4 & 3.287 & 3.89 & 2.954 & 3.326 & \\
\hline & Mean & 3.60 & & 3.07 & & \\
\hline \multirow{5}{*}{$\begin{array}{l}\text { Sulphur } \\
(\%)\end{array}$} & $\mathrm{St}-1$ & 0.603 & & 0.59 & & \multirow{5}{*}{$0.1-0.5$} \\
\hline & St-2 & 0.68 & 0.603 & 0.668 & 0.578 & \\
\hline & St-3 & 0.657 & to & 0.582 & to & \\
\hline & St-4 & 0.639 & 0.68 & 0.578 & 0.67 & \\
\hline & Mean & 0.65 & & 0.61 & & \\
\hline
\end{tabular}

Phosphorus $(P)$

The phosphorus contents in both GB and BB at all the stations were within the standard level $(0.5$ to $4.0 \%$ ) of NACC (2015). The highest phosphorus content $0.874 \%$ was measured in GB-3 and $0.79 \%$ in BB-1 that showed the content of $\mathrm{P}$ was higher in GB than BB (Table 2).

\section{Potassium (K)}

The potassium content was calculated in produced organic fertilizer and it was ranged from 3.287 to $3.890 \%$ in GB with an average of $3.606 \%$, and 2.834 to $3.326 \%$ in BB with an average of $3.062 \%$. The highest content was measured in GB-1 and BB-1 (Table 2). Comparing with standard level $(0.1$ to $3.0 \%)$ set by NACC (2015), it can be concluded that the potassium content in organic fertilizer was higher in all barrels except BB-2.

$\operatorname{Sulphur}(S)$

The sulphur contents measured in organic fertilizer ranged from 0.603 to $0.681 \%$ in GB with an average $0.645 \%$ and 0.578 to $0.668 \%$ with an average $0.601 \%$ in BB (Table 2) which was higher than standard level (0.1 to $0.5 \%)$ set by NACC (2015). The highest sulphur content was measured 
Doi: https://doi.org/10.33002/nr2581.6853.02041

in GB-2 and BB-2 and is suitable for organic farming, gardening and harvesting.

\section{Heavy metals in organic fertilizer}

\section{$\operatorname{Lead}(\mathrm{Pb})$}

The concentration of $\mathrm{Pb}$ in organic fertilizer ranges from 30.58 to $39.71 \mathrm{ppm}$ in $\mathrm{GB}$ and 22.574 to $28.048 \mathrm{ppm}$ in $\mathrm{BB}$. The highest Pb content was measured in GB-2 and BB-1 with lowest in GB-4 and BB-2 (Figure 3). According to NACC (2015), the permissible level of lead in organic fertilizer is $30 \mathrm{ppm}$. The concentrations of $\mathrm{Pb}$ were high in $\mathrm{GB}$ at all stations because of different vegetables having absorbed the heavy metal. In green barrel, there was not any moderation to prepare the organic fertilizer in barrel composting. The concentration of lead exceeded in green barrel in all the four stations. Station St-2 showed the highest concentration that is alarming for student's health. In black barrel, the concentration was below the acceptable level. So, the moderated barrel should be used for composting process.

\section{Cadmium $(C d)$}

The Cd concentration in organic fertilizer ranged from 1.57 to $2.95 \mathrm{ppm}$ in GB with highest and lowest $\mathrm{Cd}$ content was at St-2 and St-1, respectively. In BB, the Cd content ranged from 1.52 to $2.28 \mathrm{ppm}$ while highest at St-1 and lowest at St-2, respectively (Figure 4). The Cd concentration in both $\mathrm{GB}$ and $\mathrm{BB}$ at all the stations is within the standard level.

\section{Chromium $(\mathrm{Cr})$}

The $\mathrm{Cr}$ concentration of organic fertilizer (Figure 5) was highest in GB-4 (24.71 ppm) and BB-1 (21.99 ppm) whereas it was lowest in GB-2 (20.49 ppm) and BB-2 (20.37 ppm). At the same time, all the Cr concentrations at all stations were within the standard of $50 \mathrm{ppm}$ (NACC, 2015).

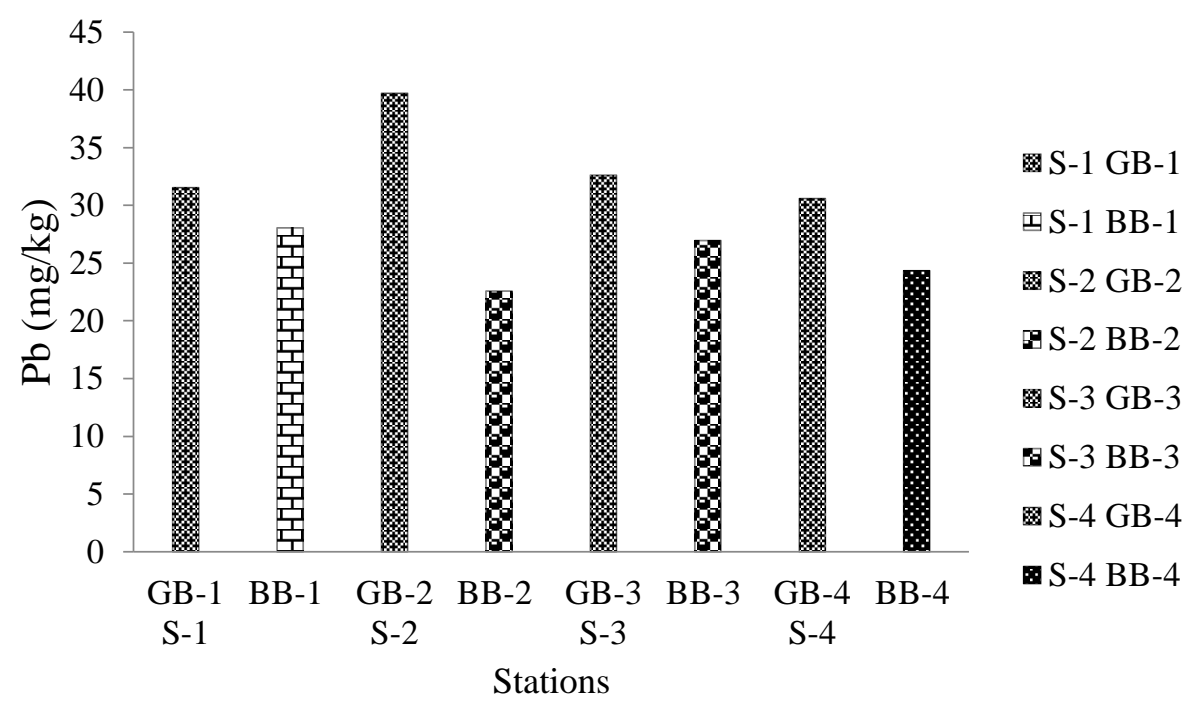

Figure 3: The $\mathrm{Pb}$ concentration of organic fertilizer at both $\mathrm{GB}$ and $\mathrm{BB}$ in four sampling stations 


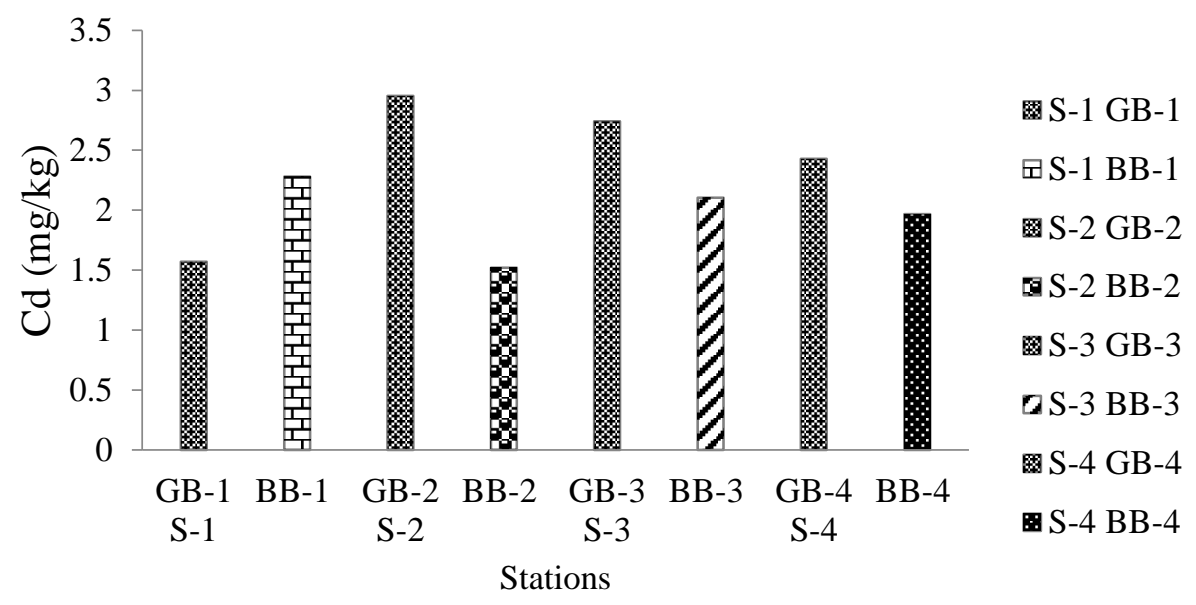

Figure 4: The Cd concentration of organic fertilizer at both GB and BB in four sampling stations

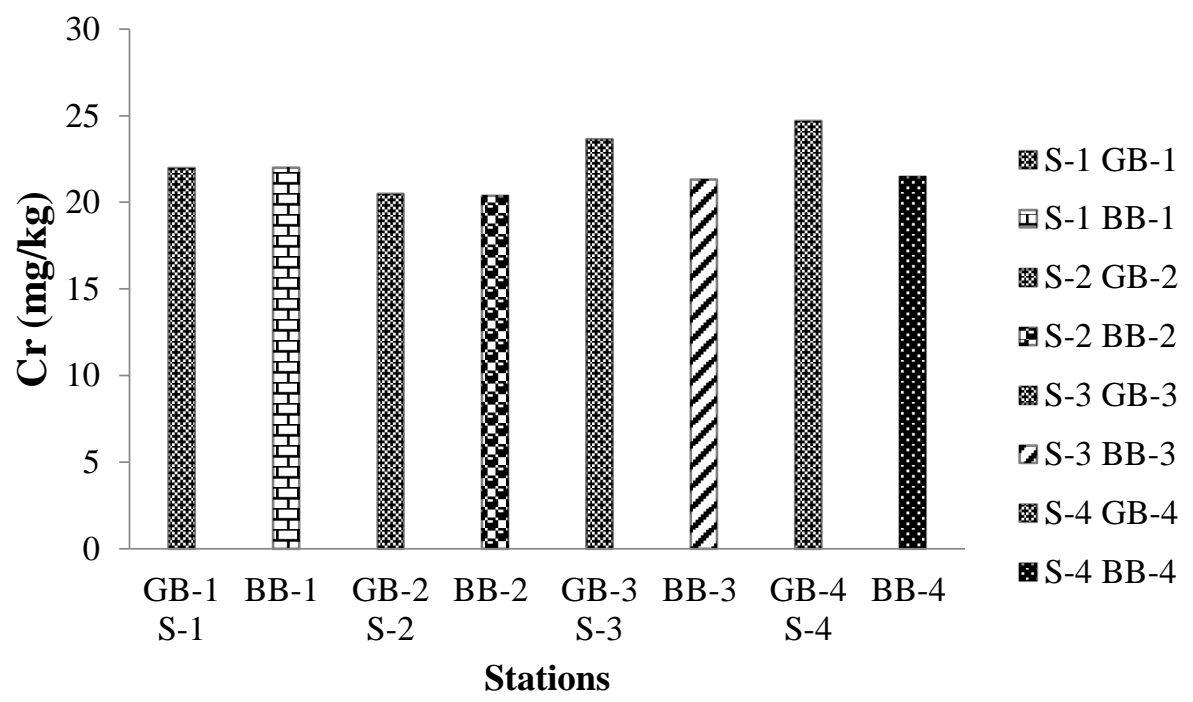

Figure 5: The Cr concentration in organic fertilizer produced from kitchen waste

\section{Pearson correlations among parameters of organic fertilizer in green and black barrels}

In $\mathrm{GB}, \mathrm{pH}$ showed positive correlation with $\mathrm{OC}, \mathrm{K}$ and $\mathrm{Pb}$ but negative correlation with moisture, TN, P, S, Cd and Cr. Moisture showed positive correlation with $\mathrm{OC}, \mathrm{TN}, \mathrm{S}, \mathrm{Pb}, \mathrm{Cd}$ and $\mathrm{Cr}$ but showed negative correlation with $\mathrm{P}$ and $\mathrm{K}$ (Table 3 ). The OC showed positive correlation with $\mathrm{K}$, $\mathrm{S}, \mathrm{Pb}$ and $\mathrm{Cd}$ but negative correlation with $\mathrm{TN}, \mathrm{P}$ and $\mathrm{Cr}$. The $\mathrm{TN}$ showed significant negative correlation with $\mathrm{K}(\mathrm{r}=-.967, \mathrm{p}<0.05)$, and the $\mathrm{S}$ showed significant positive correlation with $\mathrm{Cd}$ $(\mathrm{r}=+.981, \mathrm{p}<0.05)$. The $\mathrm{Pb}$ showed positive correlation with $\mathrm{Cd}$ but negative correlation with $\mathrm{Cr}$. The Cd showed negative correlation with $\mathrm{Cr}$.

In $\mathrm{BB}$, moisture showed significant positive correlation (Table 4) with $\mathrm{Cr}(\mathrm{r}=.991, \mathrm{p}<0.01)$ while OC showed significant negative correlation with $\mathrm{P}(\mathrm{r}=-.764, \mathrm{p}<0.05), \mathrm{K}(\mathrm{r}=-.983, \mathrm{p}<0.05)$, and $\mathrm{Pb}(\mathrm{r}=-.972, \mathrm{p}<0.05)$. The $\mathrm{K}$ showed significant positive correlation with $\mathrm{Pb}(\mathrm{r}=+.988, \mathrm{p}<0.05)$. 
Doi: https://doi.org/10.33002/nr2581.6853.02041

The $\mathrm{Pb}$ showed significant positive correlation with $\mathrm{Cd}(\mathrm{r}=+.952, \mathrm{p}<0.05)$ whereas $\mathrm{Cd}$ showed a significant positive correlation with $\mathrm{Cr}(\mathrm{r}=+.961, \mathrm{p}<0.05)$.

Table 3: Pearson correlation coefficient (r-values) among physicochemical parameters, nutrients and heavy metals of organic fertilizer in green barrel (GB)

\begin{tabular}{|c|c|c|c|c|c|c|c|c|c|c|}
\hline Parameters & $\mathrm{pH}$ & Moisture & $\mathrm{OC}$ & $\mathrm{TN}$ & $\mathrm{P}$ & $\mathrm{K}$ & $\mathrm{S}$ & $\mathrm{Pb}$ & $\mathrm{Cd}$ & $\mathrm{Cr}$ \\
\hline $\mathrm{pH}$ & 1 & & & & & & & & & \\
\hline Moisture & -.204 & 1 & & & & & & & & \\
\hline $\mathrm{OC}$ & .260 & .808 & 1 & & & & & & & \\
\hline $\mathrm{TN}$ & -.791 & .576 & $\begin{array}{c}-.00 \\
8\end{array}$ & 1 & & & & & & \\
\hline $\mathrm{P}$ & -.442 & -.238 & $\begin{array}{c}-.07 \\
9\end{array}$ & -.158 & 1 & & & & & \\
\hline K & .920 & -.458 & .106 & $-.967 *$ & $\begin{array}{c}-.08 \\
4\end{array}$ & 1 & & & & \\
\hline $\mathrm{S}$ & -.489 & .304 & .394 & .102 & .851 & -.273 & 1 & & & \\
\hline $\mathrm{Pb}$ & .195 & .243 & .678 & -.445 & .597 & .359 & .759 & 1 & & \\
\hline $\mathrm{Cd}$ & -.649 & .297 & .276 & .259 & .847 & -.439 & $.981 *$ & .618 & 1 & \\
\hline $\mathrm{Cr}$ & -.712 & .032 & $\begin{array}{c}-.56 \\
2\end{array}$ & .820 & $\begin{array}{c}-.22 \\
3\end{array}$ & -.815 & -.263 & -.821 & -.071 & 1 \\
\hline
\end{tabular}

*Correlation is significant at 0.05 levels

Table 4: Pearson correlation coefficient (r-values) among physicochemical parameters, nutrients and heavy metals of organic fertilizer in black barrel (BB)

\begin{tabular}{|c|c|c|c|c|c|c|c|c|c|c|}
\hline Parameters & $\mathrm{pH}$ & Moisture & $\mathrm{OC}$ & $\mathrm{TN}$ & $\mathrm{P}$ & $\mathrm{K}$ & $\mathrm{S}$ & $\mathrm{Pb}$ & $\mathrm{Cd}$ & $\mathrm{Cr}$ \\
\hline $\mathrm{pH}$ & 1 & & & & & & & & & \\
\hline Moisture & .631 & 1 & & & & & & & & \\
\hline $\mathrm{OC}$ & -.509 & -.658 & 1 & & & & & & & \\
\hline TN & .386 & .159 & .532 & 1 & & & & & & \\
\hline $\mathrm{P}$ & .945 & .526 & -.674 & .088 & 1 & & & & & \\
\hline K & .593 & .783 & $-.983^{*}$ & -.386 & .704 & 1 & & & & \\
\hline $\mathrm{S}$ & -.210 & -.890 & .522 & .014 & -.104 & -.631 & 1 & & & \\
\hline $\mathrm{Pb}$ & .479 & .789 & $-.972 *$ & -.446 & .587 & $.988 *$ & -.707 & 1 & & \\
\hline $\mathrm{Cd}$ & .523 & .934 & -.861 & -.200 & .531 & .931 & -.867 & $.952 *$ & 1 & \\
\hline $\mathrm{Cr}$ & .674 & $.991 * *$ & -.747 & .073 & .607 & .855 & -.853 & .853 & $.961 *$ & 1 \\
\hline
\end{tabular}

$*$ Correlation is significant at 0.05 levels, $* *$ Correlation is significant at the 0.01 levels (2-tailed).

\section{Conclusions}

Kitchen waste management through barrel composting system can provide a solution dealing with the most significant component of wastes. It reduces the weight and volume of waste and produces inoffensive and useful organic fertilizer which is enriched with nutrient. After completion of composting process, total $5.8 \mathrm{~kg}$ of organic fertilizers was produced from $178.52 \mathrm{~kg}$ of kitchen wastes. The temperature, $\mathrm{pH}$ and moisture contents of matured compost were within the optimal level indicating good quality of organic fertilizer. The content of OC, N, P and K was within the 
standard level whereas the $\mathrm{S}$ content slightly exceeded the standard. The $\mathrm{C}$ : $\mathrm{N}$ ratio ranged from 10.07 to 12 indicating that the organic fertilizer is sound in quality. The $\mathrm{Cd}$ and $\mathrm{Cr}$ concentrations in both $\mathrm{GB}$ and $\mathrm{BB}$ in four stations were within the permissible level, although high $\mathrm{Pb}$ concentration was measured in GB. So, the organic fertilizer of GB can be used only for gardening purposes. The organic fertilizer produced in BB i.e. moderated, can be used for all purposes such as commercial and agricultural production. High quality compost i.e. organic fertilizer was produced from the kitchen waste because it was collected directly from the source point of waste generation. Produced organic fertilizer through barrel composting system is energy efficient, inoffensive and nutrient rich. It helps to manage kitchen waste of the Mawlana Bhashani Science and Technology University campus and the Tangail municipality area effectively. Now it's the time to disseminate the knowledge of kitchen waste management through barrel composting system in other university campuses and municipality areas to make their environment clean, green, healthy and friendly.

\section{Acknowledgements}

Sincere appreciation to the University Grants Commission (UGC) of Bangladesh for financial support through the Research Cell of the Mawlana Bhashani Science and Technology University to carry out the research smoothly and successfully. Thanks to Mr. Mohammad Afzal Hossain (Lecturer, Department of English, MBSTU) for correcting the English of this paper.

\section{References}

Bahauddin, K.M. and M.H. Uddin (2012). Prospect of solid waste situation and an approach of environmental management measure (EMM) model for sustainable solid waste management: case study of Dhaka city. Journal of Environmental Science and Natural Resources, 5(1): 99-111.

Baca, M.T., Fornasier, F. and Nobil, M.D. (1992). Mineralization and humification pathways in two composting processes applied to cotton wastes. Journal of Fermentation and Bioengineering, 74: 179-184.

BBS (Bangladesh Bureau of Statistics) (2012). Community report, Tangail zila, Statistical Yearbook of Bangladesh. Statistics and Informatics Division, Ministry of Planning, Government of the People's Republic of Bangladesh.

Banglapedia (2016). National Encyclopedia of Bangladesh. Asiatic Society of Bangladesh, Dhaka, Bangladesh.

Cal Recycle (2006). Organic materials management- compost what is it? http://www.calrecycle.ca.gov/organics/compostmulch/compostis.htm, accessed on Jan. 3, 2013.

CWMI (Cornell Waste Management Institute) (2016). Monitoring compost pH, Cornell composting in schools. Department of Crop and Soil Sciences, Cornell University.

Dilkara, S., Pamphilon, B., Yousuf, T.B., Shah, M.I., Singh, A., Venkataramaiah, M. and Russell, K. (2016). An exploration of opportunities to utilize urban organic waste for the livelihood improvement of rural and urban communities in Bangladesh and India. Australian Center for International Agricultural Research.

Fang, M. and Wong, J.W.C. (1999). Effect of lime amendment on availability of heavy metals and maturation in sewage sludge composting. Journal of Environmental Pollution, 106(1): 8389. 
Google Earth (2017). Image landsat. US Department of State Geographer, USA.

Goyal, S., Dhull, S.K. and Kapoor, K.K. (2005). Chemical and biological changes during composting of different organic waste and assessment of compost maturity. Bioresource Technology, 96: 1584-1591.

Islam, M.S., Islam, M.M., Murshed, M.S., Saifullah, A.S.M. and Nahar, Z.M. (2011). Kitchen waste management through barrel composting system in MBSTU campus, Tangail. Bangladesh Journal of Environmental Science, 20: 47-52.

Islam, M.S., Hasan, M., Rahman, M.M., Uddin, M.N. and Kabir, M.H. (2016). Comparison between vermicompost and conventional aerobic compost produced from Municipal organic solid waste used in Amaranthus viridis production. Journal of Environmental Science and Natural Resources, 9(2): 43-49.

Li, G.X. and F.S. Zhang (2000). Solid waste composting and production of fertilizer. Beijing, China: Chinese Chemical Industry Press.

NACC (National Agriculture Coordination Committee) (2015). The People's Republic of Bangladesh, Dhaka.

Padmavathiamma, P.K., Li, L.Y. and Kumari, U.R. (2008). An experimental study of vermibiowaste composting for agricultural soil improvement. Bioresource Technology, 99: 19721681 .

Rahman, M.M. and M.A. Ali (2000). Waste management and environmental pollution in Bangladesh. In: the international conference, Bangladesh Environment, ICBEN, BUET, Dhaka, Bangladesh.

Rahman, M.H. (2004). Composting of solid waste in Bangladesh. In: The $19^{\text {th }}$ international conference on solid waste technology and management, Philadelphia, USA, 45-49 pp.

Sambali, G. and Mehrotra, R.S. (2009). Principles of microbiology. New Delhi: Tata McGraw-Hill Education Pvt. Ltd.

Sharma, B.K. (2003). Environmental chemistry. Dhaka, Bangladesh: Krishna Prokason Media Limited, 3-81pp.

Sreenivas, C., Muralidhar, S. and Rao, M.S. (2000). Vermicompost: a viable component of IPNSS in nitrogen nutrition of ridge gourd. Journal of Agricultural Research, 21(1): 108-113.

Sundberg, C. and Smars, S. (2004). Low pH as an inhibiting factor in the transition from mesophilic to thermophilic phase in composting. Bioresource Technology, 96: 746-752.

Tangail Municipality (2006). Annual report on waste management in Tangail municipality area.

Tchobanoglous, G. (1977). Solid waste: engineering principles and management issue. New York: McGraw Hill Publications Company.

Zein, A.E., Seif, H. and Gooda, E. (2015). Moisture content and thermal balance during composting of fish, banana mulch and municipal solid waste. European Scientific Journal, 11(5): 169-187. 